\title{
Arthrobacter alpinus sp. nov., a psychrophilic bacterium isolated from alpine soil
}

\author{
De-Chao Zhang, ${ }^{1}$ Peter Schumann, ${ }^{2}$ Hong-Can Liu, ${ }^{3}$ Yu-Hua Xin, ${ }^{3}$ \\ Yu-Guang Zhou, ${ }^{3}$ Franz Schinner ${ }^{1}$ and Rosa Margesin ${ }^{1}$
}

Correspondence

Rosa Margesin

Rosa.Margesin@uibk.ac.at

\author{
${ }^{1}$ Institute of Microbiology, University of Innsbruck, Technikerstrasse 25, A-6020 Innsbruck, Austria \\ ${ }^{2} \mathrm{DSMZ}$ - Deutsche Sammlung für Mikroorganismen und Zellkulturen GmbH, Inhoffenstrasse 7B, \\ D-38124 Braunschweig, Germany \\ ${ }^{3}$ China General Microbiological Culture Collection Center and State Key Laboratory of Microbial \\ Resources, Institute of Microbiology, Chinese Academy of Sciences, Beijing 100101, PR China
}

The genus Arthrobacter was proposed by Conn \& Dimmick (1947) to accommodate bacteria that show a rod-coccus growth cycle, aerobic metabolism and little or no acid production from glucose, have lysine in the peptidoglycan and a DNA G + C content of 59-66 mol\% (Keddie et al., 1986). Strains of the genus have been isolated from a variety of sources and belong to different thermal classes; several representatives are psychrophilic and are thus able to proliferate at low temperatures (Margesin et al., 2008), such as Arthrobacter psychrolactophilus (Loveland-Curtze et al., 1999), A. stackebrandtii (Tvrzová et al., 2005), A. flavus and A. roseus (Reddy et al., 2000, 2002), A. psychrophenolicus (Margesin et al., 2004b) and A. chlorophenolicus (Westerberg et al., 2000). We use the term psychrophile as a general term that describes a micro-organism that grows in a cold environment. The use of growth rates to define the optimum growth temperature as described by Morita (1975) has been shown to be ambiguous and inappropriate (Feller \& Gerday, 2003; Cavicchioli, 2006). A. psychrophenolicus and A. chlorophenolicus have been reported to be useful for bioremediation in cold climates, as they are able to degrade

The GenBank/EMBL/DDBJ accession number for the 16S rRNA gene sequence of strain $\mathrm{S} 6-3^{\top}$ is GQ227413.

A table giving the cellular fatty acid compositions of strain $S 6-3^{\top}$ and related type strains is available as supplementary material with the online version of this paper. phenolic compounds at low temperatures (Backman \& Jansson, 2004; Margesin et al., 2004a).

Members of the genus Arthrobacter Conn and Dimmick 1947, the description of which was later emended by Koch et al. (1995), fall into at least two groups (Stackebrandt \& Schumann, 2006) as revealed by chemotaxonomic studies (Minnikin et al., 1978; Collins \& Jones, 1981; Collins \& Kroppenstedt, 1983; Stackebrandt et al., 1983). The type species, Arthrobacter globiformis (Conn \& Dimmick, 1947), represents the so-called 'globiformis' group, while the second, the 'nicotianae' group, is centred around the species Arthrobacter nicotianae. The globiformis group is characterized by the presence of peptidoglycan of the A3 $\alpha$ type (i.e. an interpeptide bridge made up of one to four residues of $\mathrm{L}$-amino acids such as $\mathrm{L}$-alanine, $\mathrm{L}$-threonine or L-serine; Schleifer \& Kandler, 1972) and of a dihydrogenated menaquinone with nine isoprenoid units [MK$9\left(\mathrm{H}_{2}\right)$ ]. The 'nicotianae' group comprises organisms that have peptidoglycan variation $\mathrm{A} 4 \alpha$ (i.e. an interpeptide bridge consisting of a dicarboxylic amino acid such as glutamic acid or aspartic acid; Schleifer \& Kandler, 1972) and menaquinones that are completely unsaturated with eight to ten isoprenoid units.

Strain $56-3^{\mathrm{T}}$ was isolated during the course of a study on microbial community composition and activity over an 
alpine altitude gradient (Margesin et al., 2009). The strain was isolated from alpine soil collected in the Hohe Tauern/ Grossglockner area (Fuschertörl), Austria, on the north slope at $2300 \mathrm{~m}$ above sea level. Soil was collected under sterile conditions in August 2006. Subsequently, $10 \mathrm{~g}$ sample was shaken with $90 \mathrm{ml}$ sterile $1 \%$ sodium pyrophosphate for $20 \mathrm{~min}$ at 150 r.p.m. Appropriate dilutions, prepared with sterile saline solution $(0.9 \% \mathrm{NaCl})$, were plated $(0.1 \mathrm{ml})$ on R2A agar (Reasoner \& Geldreich, 1985) and incubated at $20^{\circ} \mathrm{C}$. One of the pure cultures was yellow-pigmented and was designated strain $\mathrm{S} 6-3^{\mathrm{T}}$.

A. stackebrandtii DSM $16005^{\mathrm{T}}$ and A. psychrolactophilus DSM $15612^{\mathrm{T}}$ were used as reference strains; they were routinely grown on trypticase soy-yeast extract medium (3\% trypticase soy broth, $0.3 \%$ yeast extract, $1.5 \%$ agar; $\mathrm{pH} 7.0-7.2)$ at $25{ }^{\circ} \mathrm{C}$.

DNA was extracted and purified as described by Sambrook et al. (1989). The gene encoding the 16S rRNA was amplified by PCR with two universal primers (Zhang et al., 2006). PCR products were cloned in pGEM-T vectors by using the pGEM-T easy vector system (Promega) according to the manufacturer's instructions. Sequencing reactions were carried out by using an $\mathrm{ABI}$ BigDye 3.1 sequencing kit (Applied BioSystems) and an automated DNA sequencer (model ABI 3730; Applied BioSystems). The nearly complete $16 \mathrm{~S}$ rRNA gene sequence $\left(1530 \mathrm{bp}\right.$ ) of strain $\mathrm{S} 6-3^{\mathrm{T}}$ was submitted to GenBank and EMBL to search for similar sequences via the BLAST algorithm. Phylogenetic trees were constructed by using Kimura's two-parameter and pairwise-deletion model analysis implemented in the program MEGA version 3.0 (Kumar et al., 2004). The resulting tree topologies were evaluated by bootstrap analysis based on 1000 replicates. Phylogenetic analysis showed that strain S6$3^{\mathrm{T}}$ was grouped with members of the genus Arthrobacter, and formed a distinct cluster with the type strains of $A$. psychrolactophilus (97.9\% 16S rRNA gene sequence similarity) and A. stackebrandtii (97.6\%) in the neighbour-joining tree (Fig. 1). Levels of 16S rRNA gene sequence similarity between strain $56-3^{\mathrm{T}}$ and the type strains of all other recognized Arthrobacter species were also $<98.0 \%$.

Strain S6- $3^{\mathrm{T}}$ was routinely cultured in low-strength R2A agar and was maintained as a suspension in skimmed milk $(10 \%, \mathrm{w} / \mathrm{v})$ at $-80{ }^{\circ} \mathrm{C}$. Cell morphology was examined by phase-contrast microscopy $(\times 1000)$ of cells grown on R2A agar plates at $20{ }^{\circ} \mathrm{C}$. Colony morphology was also observed on R2A agar plates. The API M system (bioMérieux) was used to evaluate cell motility. The Gram reaction was tested by Gram staining and was confirmed by the $\mathrm{KOH}$ lysis test. Catalase activity was determined by bubble production in $3 \%(\mathrm{v} / \mathrm{v}) \mathrm{H}_{2} \mathrm{O}_{2}$; oxidase activity was determined by using $1 \%(\mathrm{w} / \mathrm{v}) \mathrm{N}, N, N^{\prime}, N^{\prime}$-tetramethyl-p-phenylenediamine. API strips (API 20 E, API 20 NE, API Coryne, API ZYM; bioMérieux) incubated at $15-20{ }^{\circ} \mathrm{C}$ were used according to the manufacturer's instructions to determine physiological and biochemical characteristics as well as enzyme activities of strain $56-3^{\mathrm{T}}$ and reference strains $A$. stackebrandtii DSM $16005^{\mathrm{T}}$ and A. psychrolactophilus DSM $15612^{\mathrm{T}}$. In addition, assimilation of lactose, Tween 40 and Tween 80 was tested in liquid culture by supplementing $10 \mathrm{ml}$ of a $\mathrm{pH}$-neutral

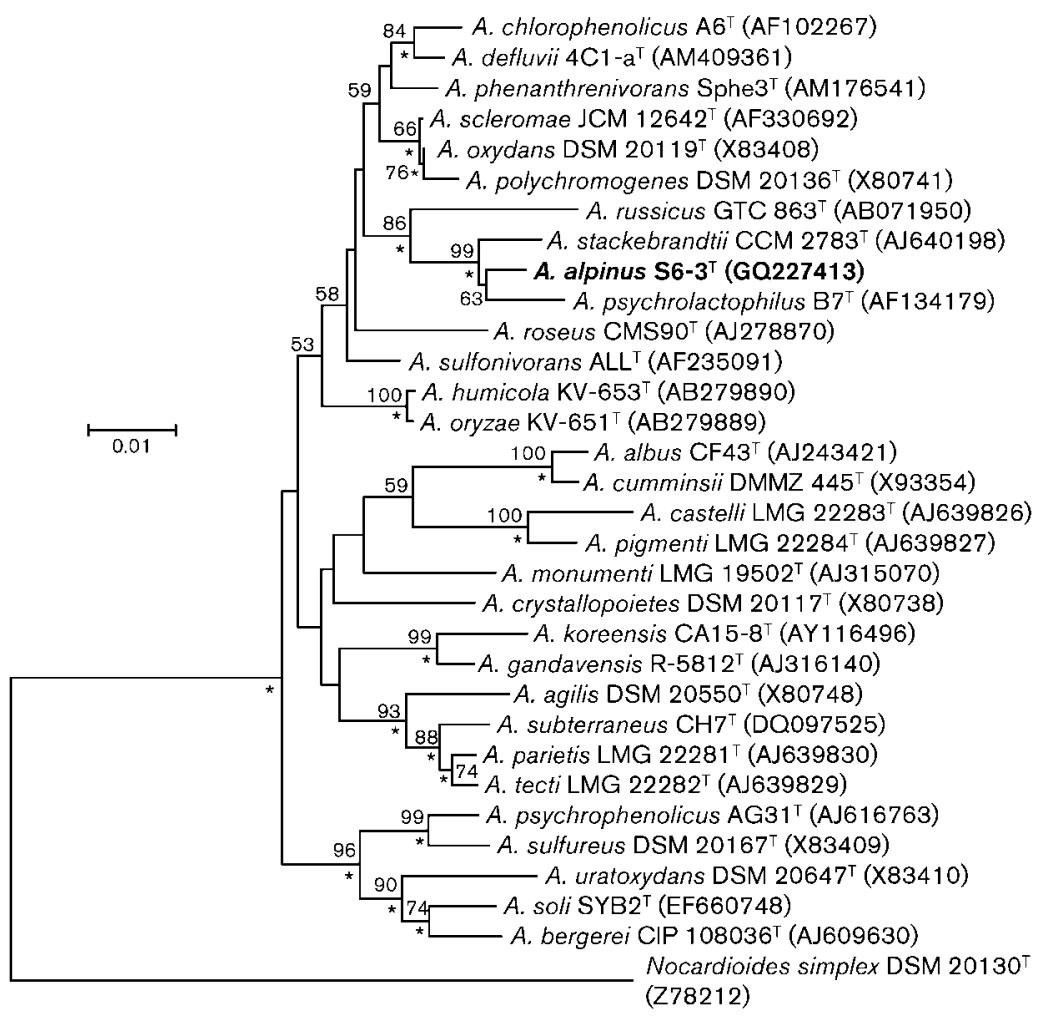

Fig. 1. Neighbour-joining tree, based on 16S rRNA gene sequence data, showing the phylogenetic position of strain $\mathrm{S} 6-3^{\top}$ and the type strains of related Arthrobacter species. Nocardioides simplex DSM $20130^{\top}$ was used as an outgroup. Asterisks indicate nodes that were also found in the maximum-parsimony (Fitch, 1971) tree. Bootstrap values (percentages) are based on 1000 replicates and are shown for branches with more than $50 \%$ support. GenBank accession numbers are given in parentheses. Bar, 0.01 expected changes per site. 
phosphate-buffered mineral medium with a trace element solution (Margesin et al., 2002) and the carbohydrates (final concentration $0.2 \%, \mathrm{w} / \mathrm{v}$ ) as the sole carbon source. Growth at $1,5,10,15,20,25$ and $30^{\circ} \mathrm{C}$ was assessed on R2A agar plates and in R2A liquid medium. Growth at $\mathrm{pH} 5,6,7,8$ and 9 and $0,1,2,3,5,7.5$ and $10 \%(\mathrm{w} / \mathrm{v}) \mathrm{NaCl}$ was determined on R2A agar plates. Susceptibility to antibiotics was determined on R2A agar plates supplemented with various antibiotics; plates were incubated at $15{ }^{\circ} \mathrm{C}$. Morphological, physiological and biochemical characteristics of strain $\mathrm{S6}-3^{\mathrm{T}}$ are given in the species description or are shown in Table 1 . The features that serve to differentiate strain $\mathrm{S} 6-3^{\mathrm{T}}$ from the phylogenetically most closely related members of the genus Arthrobacter are given in Table 1.

For analysis of the peptidoglycan structure and cell-wall sugars, cells of strain $\mathrm{S} 6-3^{\mathrm{T}}$ were cultured in shaken flasks of medium 92 (http://www.dsmz.de) at $20{ }^{\circ} \mathrm{C}$ for 3 days. The peptidoglycan structure was determined by using hydrolysates of purified cell walls according to Schleifer (1985). Amino acids and peptides were separated by twodimensional ascending TLC on cellulose plates with the solvent systems of Schleifer \& Kandler (1972). The molar ratio of the amino acids was determined by GC as described by MacKenzie (1987). The $\mathrm{N}$ terminus of the interpeptide bridge was determined by dinitrophenylation according to Schleifer (1985). The peptidoglycan of strain S6- $3^{\mathrm{T}}$ contained the amino acids lysine, alanine, threonine and glutamic acid in an approximate molar ratio of $0.8: 5.6: 1.0: 1.0$. The total hydrolysate of the peptidoglycan $\left(4 \mathrm{M} \mathrm{HCl}, 100{ }^{\circ} \mathrm{C}, 16 \mathrm{~h}\right)$ contained, in addition to these amino acids, the peptide L-Lys-L-Thr, which is relatively stable under these hydrolytic conditions. The partial hydrolysate $\left(4 \mathrm{M} \mathrm{HCl}, 100{ }^{\circ} \mathrm{C}, 0.75 \mathrm{~h}\right)$ also contained the peptides $\mathrm{Ala}_{3-4}$, L-Ala-D-Glu and D-Ala-L-LysL-Thr. Dinitrophenylation revealed that alanine represents the $\mathrm{N}$ terminus of the interpeptide bridge. From these data, it was concluded that the peptidoglycan of strain $\mathrm{S} 6-3^{\mathrm{T}}$ is of type A3 $\alpha$ L-Lys-L-Thr-Ala 3 (A11.28 according to http:// www.dsmz.de/microorganisms/main.php?content_id=35). Strain $\mathrm{S} 6-3^{\mathrm{T}}$ showed the same peptidoglycan structure as its phylogenetic neighbour A. psychrolactophilus but differed in this characteristic from A. stackebrandtii, which shows the peptidoglycan type A3 $\alpha$ L-Lys-L-Ala 2 (Tvrzová et al., 2005).

For analysis of sugars, cell walls were hydrolysed in $0.5 \mathrm{M}$ $\mathrm{H}_{2} \mathrm{SO}_{4}$ at $100{ }^{\circ} \mathrm{C}$ for $2 \mathrm{~h}$. $\mathrm{H}_{2} \mathrm{SO}_{4}$ was removed by shak-

Table 1. Phenotypic characteristics that differentiate strain $\mathrm{S} 6-3^{\top}$ from the type strains of phylogenetically related Arthrobacter species

Strains: 1, S6-3 $3^{\mathrm{T}}$; 2, A. psychrolactophilus ATCC $700733^{\mathrm{T}}$ (unless indicated, data from Loveland-Curtze et al., 1999; Tvrzová et al., 2005); 3, A. stackebrandtii CCM $2783^{\mathrm{T}}$ (Tvrzová et al., 2005); 4, A. russicus GTC $863^{\mathrm{T}}$ (Li et al., 2004). +, Positive; w, weakly positive; -, negative; NA, no data available.

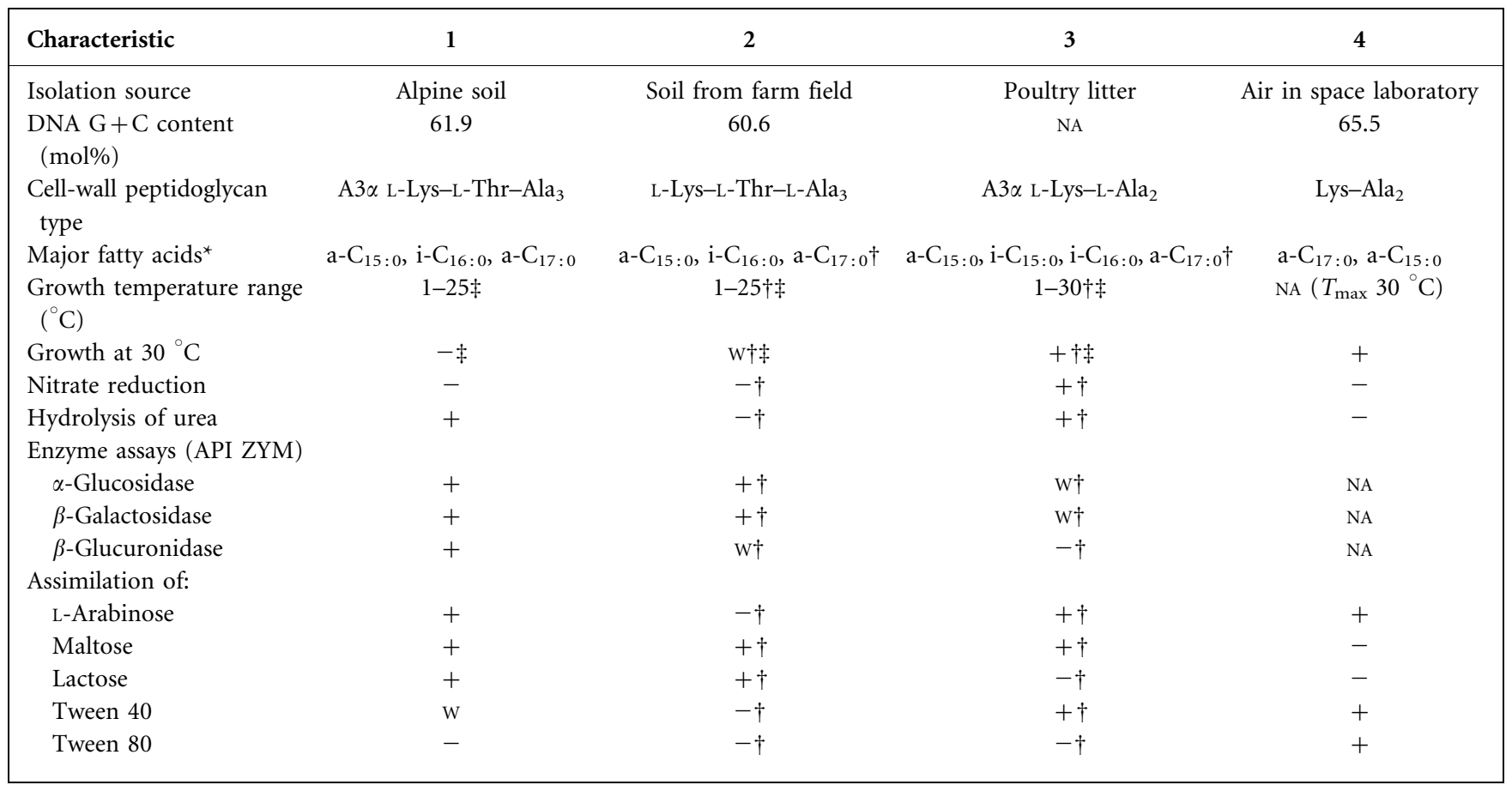

${ }^{*}$ a, Anteiso-branched; i, iso-branched.

$\dagger$ Data from the present study for A. psychrolactophilus DSM $15612^{\mathrm{T}}$ and A. stackebrandtii DSM $16005^{\mathrm{T}}$.

\$Data obtained on R2A agar plates. 
ing with $20 \% \mathrm{~N}, \mathrm{~N}$-dioctylmethylamine in chloroform according to Whiton et al. (1985) and the sugars in the hydrolysate were analysed by TLC on cellulose plates according to Staneck \& Roberts (1974). The predominant cell-wall sugars of strain $\mathrm{S6}-3^{\mathrm{T}}$ were galactose and rhamnose. An unidentified sugar component was also detected.

For analysis of fatty acid methyl esters, strain $\mathrm{S} 6-3^{\mathrm{T}}, A$. stackebrandtii DSM $16005^{\mathrm{T}}$ and A. psychrolactophilus DSM $15612^{\mathrm{T}}$ were grown on trypticase soy-yeast extract agar plates at $25{ }^{\circ} \mathrm{C}$ for 3 days. The fatty acid methyl esters were extracted and prepared according to the standard protocol of the Microbial ID system (MIDI, Inc.; Sasser, 1990). The predominant cellular fatty acids of strain $\mathrm{S} 6-3^{\mathrm{T}}$ were anteiso- $\mathrm{C}_{15: 0}(61.2 \%)$, iso- $\mathrm{C}_{16: 0}(17.9 \%)$, anteiso- $\mathrm{C}_{17: 0}$ $(10.1 \%)$ and iso- $\mathrm{C}_{15: 0}(6.2 \%)$ (the complete fatty acid profile is given in Supplementary Table S1, available in IJSEM Online). This composition was consistent with those of members of the genus Arthrobacter, showing a predominance of anteiso- $\mathrm{C}_{15: 0}$.

Respiratory quinones were extracted and purified according to Collins (1985) and were analysed by HPLC (Wu et al., 1989). Strain S6-3 $3^{\mathrm{T}}$ contained $\mathrm{MK}-9\left(\mathrm{H}_{2}\right)$ as the major menaquinone, with minor amounts of MK- $8\left(\mathrm{H}_{2}\right)$ and $\mathrm{MK}-10\left(\mathrm{H}_{2}\right)$.

The DNA G + C content was determined by the thermal denaturation method (Marmur \& Doty, 1962) with Escherichia coli K-12 as the reference, and DNA-DNA hybridization experiments were performed by the liquid renaturation method (De Ley et al., 1970) as modified by Huß et al. (1983); the two experiments were carried out by using a DU800 spectrophotometer (Beckman) with a thermal controller. The DNA G $+\mathrm{C}$ content of strain S6$3^{\mathrm{T}}$ was $61.9 \mathrm{~mol} \%$. Levels of DNA-DNA relatedness between strain $\mathrm{S} 6-3^{\mathrm{T}}$ and A. stackebrandtii DSM $16005^{\mathrm{T}}$ and A. psychrolactophilus DSM $15612^{\mathrm{T}}$ were $10.7 \pm 3.8 \%$ (mean \pm SD from three replicate determinations) and $33.8 \pm 5.2 \%$, respectively.

Strain $\mathrm{S6}-3^{\mathrm{T}}$ is a psychrophilic representative of the genus Arthrobacter and can be distinguished easily from its closest phylogenetic neighbours, A. psychrolactophilus and A. stackebrandtii, based on its inability to grow at $30{ }^{\circ} \mathrm{C}$ and from $A$. stackebrandtii based on its ability to utilize lactose and its different peptidoglycan type. Based on the phenotypic, phylogenetic and genomic evidence presented, strain $\mathrm{S} 6-3^{\mathrm{T}}$ is considered to represent a novel species of the genus Arthrobacter, for which we propose the name Arthrobacter alpinus sp. nov.

\section{Description of Arthrobacter alpinus sp. nov.}

Arthrobacter alpinus (al.pi'nus. L. masc. adj. alpinus alpine, referring to the isolation of the type strain from an alpine environment).

Cells are irregular rods showing a rod-coccus cycle, $0.8-$ $1.0 \times 1.3-1.9 \mu \mathrm{m}$ after 3 days at $20{ }^{\circ} \mathrm{C}$ on R2A agar plates, often occurring in pairs as typical V-forms. Cells are Gram- reaction-positive, aerobic and non-motile. Colonies on R2A agar and on nutrient agar are creamy yellow after 3 days and yellow after 6 days, round, convex, shiny and with an entire margin; colony diameter is $1-1.5 \mathrm{~mm}$ after 3 days at $20{ }^{\circ} \mathrm{C}$ on R2A agar. Growth occurs in liquid R2A medium and on agar plates at $1-25^{\circ} \mathrm{C}$, with fastest growth at $20-25{ }^{\circ} \mathrm{C}$; growth is absent at $30{ }^{\circ} \mathrm{C}$. On R2A agar plates, growth occurs at $\mathrm{pH} 6-9$ and in the presence of $0-5 \%(\mathrm{w} /$ v) $\mathrm{NaCl}$. Produces catalase; cytochrome oxidase is not produced. Negative for nitrate reduction, indole production, $\mathrm{H}_{2} \mathrm{~S}$ production and citrate utilization. Hydrolyses aesculin, urea and starch, but not casein or Tween 80 . Negative for activities of arginine dihydrolase, lysine dihydrolase, ornithine dihydrolase, lipase (C14), $\mathrm{N}$-acetyl$\beta$-glucosaminidase, trypsin, $\alpha$-chymotrypsin, $\alpha$-fucosidase and pyrrolidonyl arylamidase. Positive for activities of alkaline phosphatase, acidic phosphatase, esterase (C4), esterase lipase (C8), leucine arylamidase, naphthol-AS-BIphosphohydrolase, $\alpha$-glucosidase, $\beta$-glucosidase, $\alpha$-galactosidase, $\beta$-galactosidase, $\beta$-glucuronidase and $\alpha$-mannosidase. Utilizes D-glucose, lactose, L-arabinose, maltose, Dmannose, D-mannitol and $\mathrm{N}$-acetylglucosamine as sole carbon source, utilizes Tween 40 weakly and does not utilize citrate, capric acid, adipic acid or phenylacetic acid. Negative for fermentation of glucose, ribose, xylose, mannitol, maltose, lactose, sucrose, glycogen, inositol, sorbitol, rhamnose, melibiose, amygdalin and L-arabinose. Sensitive to ampicillin, penicillin G, streptomycin, tetracycline and chloramphenicol (each at $30 \mu \mathrm{g} \mathrm{ml}^{-1}$ ), but resistant to cyclosporin A $\left(100 \mu \mathrm{g} \mathrm{ml}^{-1}\right)$. The predominant cellular fatty acids of the type strain are anteiso- $\mathrm{C}_{15: 0}$, iso$\mathrm{C}_{16: 0}$ and anteiso- $\mathrm{C}_{17: 0}$. Contains MK-9 $\left(\mathrm{H}_{2}\right)$ as the major menaquinone, with minor amounts of $\mathrm{MK}-8\left(\mathrm{H}_{2}\right)$ and MK$10\left(\mathrm{H}_{2}\right)$. The cell-wall peptidoglycan is of type A3 $\alpha$ L-Lys-LThr-Ala ${ }_{3}$ The predominant cell-wall sugars are galactose and rhamnose. The DNA G $+\mathrm{C}$ content of the type strain is $61.9 \mathrm{~mol} \%$.

The type strain, S6-3 ${ }^{\mathrm{T}} \quad\left(=\mathrm{DSM} \quad 22274^{\mathrm{T}}=\mathrm{CGMCC}\right.$ $1.8950^{\mathrm{T}}$ ), was isolated from an alpine soil in Fuschertörl, Hohe Tauern, Austria.

\section{Acknowledgements}

We thank K. Weber and P. Thurnbichler for technical assistance and Gabriele Pötter (DSMZ) for analysis of cellular fatty acids.

\section{References}

Backman, A. \& Jansson, J. (2004). Degradation of 4-chlorophenol at low temperature and during extreme temperature fluctuations by Arthrobacter chlorophenolicus A6. Microb Ecol 48, 246-253.

Cavicchioli, R. (2006). Cold-adapted archaea. Nature Rev Microbiol 4, 331-343.

Collins, M. D. (1985). Isoprenoid quinone analysis in classification and identification. In Chemical Methods in Bacterial Systematics, pp. 267-287. Edited by M. Goodfellow \& D. E. Minnikin. London: Academic Press. 
Collins, M. D. \& Jones, D. (1981). Distribution of isoprenoid quinone structural types in bacteria and their taxonomic implications. Microbiol Rev 45, 316-354.

Collins, M. D. \& Kroppenstedt, R. M. (1983). Lipid composition as a guide to the classification of some coryneform bacteria containing an A4 type peptidoglycan (Schleifer and Kandler). Syst Appl Microbiol 4, 95-104.

Conn, H. J. \& Dimmick, I. (1947). Soil bacteria similar in morphology to Mycobacterium and Corynebacterium. J Bacteriol 54, 291-303.

De Ley, J., Cattoir, H. \& Reynaerts, A. (1970). The quantitative measurement of DNA hybridization from renaturation rates. Eur $J$ Biochem 12, 133-142.

Feller, G. \& Gerday, C. (2003). Psychrophilic enzymes: hot topics in cold adaptation. Nature Rev Microbiol 1, 200-208.

Fitch, W. M. (1971). Toward defining the course of evolution: minimum change for a specific tree topology. Syst Zool 20, 406-416.

Huß, V. A. R., Festl, H. \& Schleifer, K. H. (1983). Studies on the spectrophotometric determination of DNA hybridization from renaturation rates. Syst Appl Microbiol 4, 184-192.

Keddie, R. M., Collins, M. D. \& Jones, D. (1986). Genus Arthrobacter Conn and Dimmick 1947, 300 ${ }^{\mathrm{AL}}$. In Bergey's Manual of Systematic Bacteriology, vol. 2, pp. 1288-1301. Edited by P. H. A. Sneath, N. S. Mair, M. E. Sharpe \& J. G. Holt. Baltimore: Williams \& Wilkins.

Koch, C., Schumann, P. \& Stackebrandt, E. (1995). Reclassification of Micrococcus agilis (Ali-Cohen 1889) to the genus Arthrobacter as Arthrobacter agilis comb. nov. and emendation of the genus Arthrobacter. Int J Syst Bacteriol 45, 837-839.

Kumar, S., Tamura, K. \& Nei, M. (2004). MEGA3: integrated software for molecular evolutionary genetics analysis and sequence alignment. Brief Bioinform 5, 150-163.

Li, Y., Kawamura, Y., Fujiwara, N., Naka, T., Liu, H., Huang, X., Kobayashi, K. \& Ezaki, T. (2004). Rothia aeria sp. nov., Rhodococcus baikonurensis sp. nov. and Arthrobacter russicus sp. nov., isolated from air in the Russian space laboratory Mir. Int J Syst Evol Microbiol 54, 827-835.

Loveland-Curtze, J., Sheridan, P. P., Gutshall, K. R. \& Brenchley, J. E. (1999). Biochemical and phylogenetic analyses of psychrophilic isolates belonging to the Arthrobacter subgroup and description of Arthrobacter psychrolactophilus sp. nov. Arch Microbiol 171, 355-363.

MacKenzie, S. L. (1987). Gas chromatographic analysis of amino acids as the $\mathrm{N}$-heptafluorobutyryl isobutyl esters. J Assoc Off Anal Chem 70, 151-160.

Margesin, R., Zacke, G. \& Schinner, F. (2002). Characterization of heterotrophic microorganisms in alpine glacier cryoconite. Arct Antarct Alp Res 34, 88-93.

Margesin, R., Bergauer, B. \& Gander, S. (2004a). Degradation of phenol and toxicity of phenolic compounds: a comparison of coldtolerant Arthrobacter sp. and mesophilic Pseudomonas putida. Extremophiles 8, 201-207.

Margesin, R., Schumann, P., Spröer, C. \& Gounot, A. M. (2004b). Arthrobacter psychrophenolicus sp. nov., isolated from an alpine ice cave. Int J Syst Evol Microbiol 54, 2067-2072.

Margesin, R., Schinner, F., Marx, J. C. \& Gerday, C. (2008). Psychrophiles: from Biodiversity to Biotechnology. Berlin: Springer.

Margesin, R., Jud, M., Tscherko, D. \& Schinner, F. (2009). Microbial communities and activities in alpine and subalpine soils. FEMS Microbiol Ecol 67, 208-218.

Marmur, J. \& Doty, P. (1962). Determination of the base composition of deoxyribonucleic acid from its thermal denaturation temperature. J Mol Biol 5, 109-118.
Minnikin, D. E., Goodfellow, M. \& Collins, M. D. (1978). Coryneform bacteria. In Lipid Composition in the Classification and Identification of Coryneform and Related Taxa, pp. 85-160. Edited by I. J. Bousfield \& A. G. Callely. London: Academic Press.

Morita, R. Y. (1975). Psychrophilic bacteria. Bacteriol Rev 39, 144-167.

Reasoner, D. J. \& Geldreich, E. E. (1985). A new medium for the enumeration and subculture of bacteria from potable water. Appl Environ Microbiol 49, 1-7.

Reddy, G. S. N., Aggarwal, R. K., Matsumoto, G. I., Stackebrandt, E. \& Shivaji, S. (2000). Arthrobacter flavus sp. nov., a psychrophilic bacterium isolated from a pond in McMurdo Dry Valley, Antarctica. Int J Syst Evol Microbiol 50, 1553-1561.

Reddy, G. S. N., Prakash, J. S. S., Matsumoto, G. I., Stackebrandt, E. \& Shivaji, S. (2002). Arthrobacter roseus sp. nov., a psychrophilic bacterium isolated from an Antarctic cyanobacterial mat sample. Int $J$ Syst Evol Microbiol 52, 1017-1021.

Sambrook, J., Frisch, E. F. \& Maniatis, T. (1989). Molecular Cloning: a Laboratory Manual, 2nd edn. Cold Spring Harbor, NY: Cold Spring Harbor Laboratory.

Sasser, M. (1990). Identification of bacteria by gas chromatography of cellular fatty acids, MIDI Technical Note 101. Newark, DE: MIDI Inc.

Schleifer, K. H. (1985). Analysis of the chemical composition and primary structure of murein. Methods Microbiol 18, 123-156.

Schleifer, K. H. \& Kandler, O. (1972). Peptidoglycan types of bacterial cell walls and their taxonomic implications. Bacteriol Rev 36, 407477.

Stackebrandt, E. \& Schumann, P. (2006). Introduction to the taxonomy of actinobacteria. In The Prokaryotes. A Handbook on the Biology of Bacteria, 3rd edn, vol. 3, pp. 297-321. Edited by M. Dworkin, S. Falkow, E. Rosenberg, K. H. Schleifer \& E. Stackebrandt. New York: Springer.

Stackebrandt, E., Fowler, V. J., Fiedler, F. \& Seiler, H. (1983). Taxonomic studies on Arthrobacter nicotianae and related taxa: description of Arthrobacter uratoxydans sp. nov. and Arthrobacter sulfureus sp. nov. and reclassification of Brevibacterium protophormiae as Arthrobacter protophormiae comb. nov. Syst Appl Microbiol 4, 470486.

Staneck, J. L. \& Roberts, G. D. (1974). Simplified approach to identification of aerobic actinomycetes by thin-layer chromatography. Appl Microbiol 28, 226-231.

Tvrzová, L., Schumann, P., Spröer, C., Sedláček, I., Verbarg, S., Kroppenstedt, R. M. \& Páčová, Z. (2005). Polyphasic taxonomic study of strain CCM 2783 resulting in the description of Arthrobacter stackebrandtii sp. nov. Int J Syst Evol Microbiol 55, 805-808.

Westerberg, K., Elväng, A. M., Stackebrandt, E. \& Jansson, J. K. (2000). Arthrobacter chlorophenolicus sp. nov., a new species capable of degrading high concentrations of 4-chlorophenol. Int J Syst Evol Microbiol 50, 2083-2092.

Whiton, R. S., Lau, P., Morgan, S. L., Gilbart, J. \& Fox, A. (1985). Modifications in the alditol acetate method for analysis of muramic acid and other neutral and amino sugars by capillary gas chromatography-mass spectrometry with selected ion monitoring. J Chromatogr A 347, 109-120.

Wu, C., Lu, X., Qin, M., Wang, Y. \& Ruan, J. (1989). Analysis of menaquinone compound in microbial cells by HPLC. Microbiology [English translation of Microbiology (Beijing)] 16, 176-178.

Zhang, D.-C., Wang, H.-X., Liu, H.-C., Dong, X.-Z. \& Zhou, P.-J. (2006). Flavobacterium glaciei sp. nov., a novel psychrophilic bacterium isolated from the China No.1 glacier. Int J Syst Evol Microbiol 56, 2921-2925. 